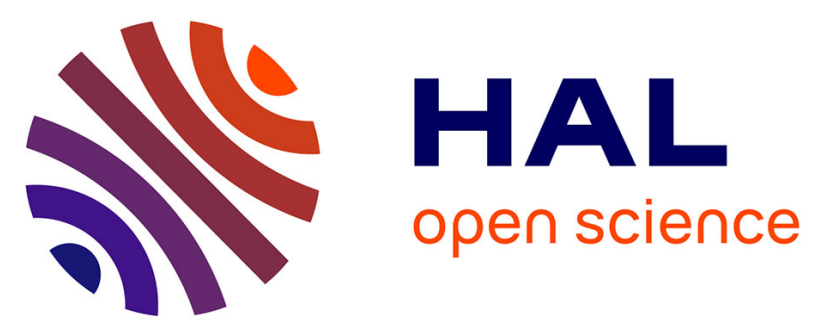

\title{
Association between Salivary Hypofunction and Food Consumption in the Elderlies. A Systematic Literature Review
}

Carolina Muñoz-González, Mathilde Vandenberghe-Descamps, Gilles Feron, Francis Canon, Hélène Labouré, Claire Sulmont-Rossé

\section{To cite this version:}

Carolina Muñoz-González, Mathilde Vandenberghe-Descamps, Gilles Feron, Francis Canon, Hélène Labouré, et al.. Association between Salivary Hypofunction and Food Consumption in the Elderlies. A Systematic Literature Review. Journal of Nutrition, Health \& Aging, 2018, 22 (3), pp.407-419. 10.1007/s12603-017-0960-x . hal-02142405

\section{HAL Id: hal-02142405 \\ https://institut-agro-dijon.hal.science/hal-02142405}

Submitted on 18 Feb 2021

HAL is a multi-disciplinary open access archive for the deposit and dissemination of scientific research documents, whether they are published or not. The documents may come from teaching and research institutions in France or abroad, or from public or private research centers.
L'archive ouverte pluridisciplinaire HAL, est destinée au dépôt et à la diffusion de documents scientifiques de niveau recherche, publiés ou non, émanant des établissements d'enseignement et de recherche français ou étrangers, des laboratoires publics ou privés. 


\author{
1 ASSOCIATION BETWEEN SALIVARY HYPOFUNCTION AND FOOD \\ 2 CONSUMPTION IN THE ELDERLIES. A SYSTEMATIC LITERATURE REVIEW \\ 3 \\ 4 \\ 5 \\ 6 \\ 7 \\ 8 \\ 9 \\ 10 \\ 11 \\ 12 \\ 13 Telephone: +33380693271 1:SẸp? \\ 14 \\ 15 \\ 16 \\ Carolina Muñoz-González, Mathilde Vandenberghe-Descamps, \\ Gilles Feron, Francis Canon, Hélène Labouré, Claire Sulmont-Rossé* \\ Centre des Sciences du Goût CNRS, INRA, Université de Bourgogne Franche-Comté, \\ F-21000 Dijon, France \\ Mailing address: 17 rue Sully, F-21000 Dijon, France. \\ E-mail address: claire.sulmont-rosse@inra.fr
}

17

18

19

\section{Abstract}

Objective: This systematic literature review aims to summarize the existing scientific evidence about the association between a reduced salivary function and food consumption in elderly people. Methods: A validated search strategy in two databases (PubMed and ISI Web of Knowledge) was carried out and retrieved papers together with their reference lists were screened by two independent reviewers. The quality of the included studies was critically appraised via the Quality Assessment Criteria for Evaluating Primary Research Papers. Results: From the originally identified studies ( $\mathrm{n}=391)$, only 15 articles (all cross-sectional studies) met the pre-fixed inclusion/exclusion criteria. The methodological quality of the included studies was in general good, although only 3 from 15 obtained the maximum score. The control of 
confounding factors was the quality variable more poorly rated in the selected studies. Salivary hypofunction was associated with a decrease of the objective chewing and swallowing abilities and taste perception. Moreover, most of the selected studies showed a relationship between salivary hypofunction and food consumption (in terms of appetite loss, unbalanced dietary intake and malnutrition), although no causality could be established. Conclusions: This study highlights the fact that salivary hypofunction definition and measurements are different across the studies. Therefore, future research efforts should focus on establishing a gold standard to define and identify salivary hypofunction throughout life and on performing longitudinal studies controlling for confounding factors to establish causality.

\section{Keywords}

Hyposalivation, dietary intake, appetite, nutritional status, elderly

\section{Introduction}

Saliva is a complex biological fluid composed by water, inorganic and organic molecules (1). Secreted by several salivary glands, saliva plays an important role in the preservation and maintenance of oral health and functions (2). First, saliva is known to be essential in fulfilling daily activities such as speaking. Second, it exerts a key role maintaining oral health under normal conditions: tooth and oral mucosa integrity, protection against dental caries, periodontal diseases, etc. $(3 ; 4 ; 5)$. Third, as the first digestive fluid in contact with food, saliva is a key factor assisting the oral processing of food, whereby food is transformed into a bolus to be swallowed. During the mastication process, the lubrication function of saliva allows moistening of food and supports the creation of a bolus which in turn facilitates the ability to chew (6). Furthermore, some food components are released from the food matrix and dissolved in saliva, 
where they can be influenced by the presence of salivary components such as salivary enzymes that begin the process of food digestion (i.e. alpha-amylase) or metabolize flavor compounds (i.e. esterases, glycosidases) $(7 ; 8)$.

In consequence, an alteration in the composition or amount of saliva released to the human mouth, produced as a consequence of a diminished salivary gland function, could have serious consequences. A reduced salivary output could induce a defect in lubrication, compromising the comfort while chewing and swallowing (3). These dysfunctions could be accompanied by an unbalanced flavor perception that could provoke an unpleasant sensory experience. Besides these effects, if the situation of dry mouth is maintained in the long term, the decline (or absence) of salivation per se may change the oral environment, which could cause infections, destruction of taste receptors (9) and formation of dental caries, which can derive in tooth losses (4), thus compromising even more the food oral processing. The sum of these events could therefore provoke a decline in food interest and a loss of appetite, resulting in a modification of people's dietary habits. The quantity, quality and variety of food consumed could be altered, thus contributing to a diminished nutritional status.

This cascade of reactions possibly induced by a reduced salivary output is of especial relevance for elderly people, the population group most affected by salivary disorders. Older people are more likely to take medications compared to other generations, which is a well-known factor of hyposalivation as a side effect (10). A recent meta-analysis has shown that the aging process is associated with reduced salivary flow per se in a salivary-gland-manner (11), and this reduction can not be fully explained on the basis of medications (11) or dental status (12). In the same time, this age group is frequently associated with poor appetite, weight loss and malnutrition $(13 ; 14)$. However, the relationship between food consumption and salivary hypofunction in elderly population remains unclear. This could be due to the fact that very often 
73 the studies on this topic have measured the subjective sensation of dry mouth (xerostomia)

74 instead of performing real measurements of saliva deficiencies $(3 ; 15 ; 16 ; 17 ; 18 ; 19)$. Indeed, 75 xerostomia and hyposalivation are two separate entities, which are not always correlated (20;

76 21). Whereas xerostomia relates to a subjective evaluation of dry mouth, hyposalivation 77 represents a decrease in the amount of saliva secreted to the oral cavity. Therefore the aim of 78 this work was to systematically review the original articles studying the associations between 79 salivary hypofunction measured objectively and alterations in food consumption in elderly 80 population. In this review, food consumption has been addressed by the study of i) food oral 81 processing, ii) food behavior (appetite and dietary intake) and iii) nutritional status. Out of scope 82 of this article are external factors affecting food consumption such as food availability, cultural 83 factors, etc.

\section{2. Method}

\subsection{Search strategy}

A review of the literature was conducted in September 2016 for all published articles containing information about the association between salivary hypofunction and i) food oral processing, ii) food behavior (appetite and dietary intake), and iii) nutritional status in the elderlies. The electronic databases PubMed and ISI Web of Knowledge were used to search for relevant articles (without date restriction). The search strategy consisted of a set of Medical Subject

91 Headings (MeSH) terms and free text words subsequently combined. Following groups of key

92 words were introduced:

93 1) food oral processing, mastication, chewing, swallowing, flavo(u)r, taste, aroma, texture,

94 flavo(u)r perception, taste perception, aroma perception, texture perception, chemosensory 
perception, orosensory perception, food sensory perception, texture modification, aroma release, taste release, trigeminal sensation(s), food texture;

2) food consumption, food behavio(u)r, nutrition, appetite, food intake, malnutrition, undernutrition, malnourishment, eating, nutrient intake, eating capability, food liking, dietary pattern, meal frequency, eating frequency;

3) elderly, senior, ag(e)ing, old age, older adult(s), old(er) people, old(er) person(s);

4) saliva, hyposalivation, salivary flow, salivary composition, salivary protein(s), salivary secretion(s), salivary hypofunction, xerostomia, dry mouth, oral mucosa, mucosal wetness, mucosa dryness, oral dryness.

\subsection{Selection criteria and study selection}

Articles were included if they explored the association between an objective measure of salivary deficiencies and i) food oral processing (mastication, swallowing, orosensory perception), ii) food behavior (appetite and food intake) or iii) nutritional status. Only articles that defined salivary hypofunction were included in this systematic literature review (SLR). Therefore articles that did not explore populations with salivary disorders or that did not specify cut-off values of saliva deficiencies were not included in this SLR. Study design and settings were not defined as exclusion criteria because of the exploratory character of the review. Only articles written in English were included, no date limitation was performed.

Two reviewers (CMG and MVD) independently screened the titles and abstracts based on the selection criteria. If the abstract did not provide enough information to decide upon inclusion/exclusion, the full paper was retrieved for further screening. Disagreements about inclusion or exclusion were discussed between the reviewers until consensus was reached. 


\subsection{Data abstraction and synthesis}

118 Two reviewers (CMG and MVD) independently extracted data from the included articles. The

119 extracted data included study characteristics (author and year of publication, study design,

120 sample size, settings (living condition), determinant, outcome, methods, main results and

121 conclusions), and participant characteristics (age, gender, country/ethnicity, functional status).

122 A synthesis of the data is reported in Table 1.

Table 1 about here

\section{$124 \quad$ 2.4. Quality assessment}

125 The quality assessment of the review is based on "The quality assessment criteria for evaluating

126 primary research papers from a variety of fields" (22). The used checklist contains the following 127 items:

$128 \quad$ 1. Is the objective of the study sufficiently described?

1292 2. Is the study design evident and appropriate?

$130 \quad 3 . \quad$ Is the method of subject selection described and appropriate?

131 4. Are subject characteristics sufficiently described (functional status, health, etc.)?

1325 5. Are outcome measures well defined and robust to measurement?

1336 . Is the sample size appropriate?

134 7. Are analytic methods described, justified and appropriate?

1358 . Is some estimate of variance reported for main results?

1369 9. Are they controlled for confounding? 
139 Each question can be answered with 'yes', 'partial', 'no' and 'not applicable'. The summary

140 score is the total sum ((number of 'yes' $x$ 2) + (number of 'partial' $x 1))$ / total possible sum (28

$141-$ (number of 'not applicable' $\mathrm{x}$ 2). The associated scoring manual (22) was used to guide the

142 scoring process. When the quality of a paper was debatable, a discussion between two

143 independent reviewers was held until consensus was reached.

\section{3. Results}

\subsection{Selected articles}

146 Figure 1 shows the overview of the search strategy. A total of 391 articles were identified:

147 PubMed $(n=219)$, and ISI Web of Knowledge $(n=172)$. Duplicate articles $(n=102)$ were

148 excluded. Additionally, 248 articles were excluded because the inclusion criteria (based on title

149 and/or abstract) were not met. The full texts of 41 articles were reviewed in detail. Twenty eight

150 articles were excluded due to different reasons: not an objective measurement of the saliva flow

151 but a subjective sensation of dry mouth $(n=11)$, the relationship between the variables was not

152 explored $(n=3)$, cut-off value to determine salivary hypofunction not specified $(n=7)$, the

153 outcome measurements were not focused specifically on our research topic $(n=3)$, redundant

154 information due to a publication on the same data $(n=2)$, or not original papers but reviews

$155(\mathrm{n}=2)$. The reference lists of all included articles were checked for additional articles. In

156 consequence, four new papers were found to be of interest for this review but two of them (23;

157 24) were not written in English, so not included in the final list. The final group consisted of 15

158 articles. All of them were subjected to a methodological quality assessment. 


\subsection{Methodological quality}

161 The methodological quality of the included studies was in general good: of the 15 selected

162 articles the quality scores varied between 0.77 and 1 in a 0 -to- 1 rating scale (Table 2 ). Three articles $(25 ; 26 ; 27)$ obtained the maximum score according to the above-mentioned manual scoring (22). On the contrary, the lowest score was attributed to the study carried out by (28), the one with the smallest sample size $(n=51)$ (item $\left.n^{\circ} 6\right)$. Moreover, in this work the study design (item $n^{\circ} 2$ ), the analytical methods employed (item $n^{\circ} 7$ ) and the results (item $n^{\circ} 10$ ) were not sufficiently described. Furthermore, confounding factors (item $n^{\circ}$ 9) were partially taken into account.

In fact, the control of confounding factors (item $n^{\circ} 9$ ) was the quality variable more poorly rated in the selected studies. This was due to the fact that most of the studies did not take into account all the factors established as confounding in this study: age, gender, drug intake, diseases, mental status, socio-economic status, dental status and place to live. Therefore this item was

173 often rated as "partial".

\subsection{Study characteristics}

176 Table 1 gives an overview of the 15 selected articles. Publication year of the studies ranged

177 from 1998 to 2016, showing that the interest on this topic is held and even increased over time 178 (from 1998 to 2004: 4 studies; from 2005 to 2011: 4 studies; from 2012 to 2016: 7 studies). All

179 the studies had a cross-sectional design. The studies were based on populations from all over

180 the world (Brazil: 1, Finland: 2, Japan: 5, Norway: 1, Switzerland: 2, Thailand: 2; France:1; 181 India:1), with exception of the African and Oceanic continent and north America. The sample 
182

183

184

size varied from 51 (28) to 640 (29) subjects. The gender distribution of subjects varied between $46 \%$ (30) and $78 \%$ (28) of females. Eighty per cent of the studies presented however, a higher percentage of women compared to men. The mean age was highly dispersed in the selected studies, ranging from 66 to 84 years old. The recruited populations were located either in institutions ( 5 studies) or in their own homes (10 studies). The subjects recruited in the selected studies were in good general health except for three studies: one study with hospitalized very sick volunteers (31), one study which included subjects receiving home care nurses visits (28) and one study (27) where the elderlies were living in their own homes prior to hospitalization for acute medical problems.

\subsection{Analytical methods}

Salivary hypofunction was determined differently across the selected studies (Table 3). Fourteen of the 15 studies measured the salivary flow rate either at rest, under stimulation by chewing a piece of paraffin-wax during saliva collection or both at rest and under stimulation. Most of these studies used the spitting method for the salivary collection but some preferred to measure the salivary flow using the draining method or the sterile compress method. The draining method consists in allowing saliva to drain out between parted lips into a test tube held near the mouth. The sterile compress method consists in placing a sterile compress under the tongue, then weighting the compress after a certain time to evaluate the amount of saliva incorporated. These studies have defined salivary hypofunction when the salivary flow was below a certain cut-off value. This reference value was $0.1 \mathrm{ml} / \mathrm{min}$ of saliva determined at rest in all the selected studies. However, the cut-off values employed to define salivary hypofunction under stimulation were not consensual and varied from $0.5 \mathrm{ml} / \mathrm{min}$ to $1.0 \mathrm{ml} / \mathrm{min}$ in the different studies. Very few studies have determined salivary hypofunction using alternative methods. Four over fifteen articles employed (besides the determination of salivary 
flow) additional measures to determine salivary hypofunction, such as the mirror test (that

207 consists of measuring the stickiness of buccal mucosa when passing through it the back of a 208 dental mirror) or the registration of dry tongue (presence of moisture or not). Only one study 209 (32) did not use salivary flow to define hyposalivation. Authors measured the moisture of the 210 buccal mucosa by using a device that evaluates the weight percentage of water found in the 211 mucosa, and determined salivary hypofunction when the moisture of oral mucosa was below $21228.3 \%$ according to a previous study that validated the method (33).

\section{5. Association between salivary hypofunction and food oral processing (8 studies)}

216 The relationship between a diminished salivary function and food oral processing 217 (mastication/chewing, swallowing, orosensory perception) has been examined in 8 articles (25; $21827 ; 29 ; 30 ; 31 ; 32 ; 34 ; 35)$. Only 3 studies measured objectively chewing, swallowing and taste 219 abilities $(27 ; 31 ; 34)$, while the others $(n=5)$ employed questionnaires. The objective measurements consisted of the determination of masticatory performance, signs of dysphagia and taste ability. The evaluation of masticatory performance was achieved by measuring the amount of dissolved glucose after the mastication of test gummy jellies. The signs of dysphagia were reported using the water test during which the volunteers were asked to swallow four times an increasing volume of water to report any abnormal signs (coughing or voice modification).

225 Finally, the taste ability test consisted in impregnating some strips with sweet, salty and bitter 226 taste, then asking the volunteers to identify the tastes by putting the strips in the anterior region 227 of the tongue.

228 Six of the eight studies investigated the association between salivary hypofunction and the 229 chewing and/or swallowing abilities $(25 ; 30 ; 31 ; 32 ; 34 ; 35)$. Ikebe and coworkers (2006)(34) 
230 found a significant association between lower values of masticatory performance and 231 hyposalivation in independently living older adults. In another study with hospitalized very sick 232 older patients, Poisson and collaborators (2014)(31) found a strong relationship at univariate 233 level between individuals presenting a low salivary flow $(<0.1 \mathrm{~g} / \mathrm{min})$ and dysphagia. However 234 this effect was not observed at multivariate level, when considering other independent variables 235 in the model. The rest of the studies evaluated chewing and/or swallowing abilities through 236 questionnaires. Two works $(25 ; 35)$ found a significant association between reduced saliva flow rate and perceived chewing and swallowing difficulties. Ikebe and collaborators (2002)(30) also

238 found a relationship between hyposalivation and poor self-assessed chewing ability though it 239 was not of statistical level. Finally, Shinkawa et al., (2009)(32) found a significant association 240 between oral dryness (measured via the level of moisture of oral mucosa) and poor self-assessed 241 chewing ability but no with swallowing.

242 The association between salivary gland hypofunction and orosensory perception was evaluated 243 in four studies $(27 ; 29 ; 30 ; 35)$. However, it is important to notice that all of them were only 244 focused on one modality of flavor perception: taste. In these studies, taste ability was evaluated 245 either objectively (taste detection through the filter-paper disc method) or by questionnaires 246 considering taste as a marker for oral function (dissatisfaction with tasting). Only Solemdal et 247 al., (2012)(27) studied the association of salivary hypofunction on the objective taste ability. 248 These authors reported a significant and markedly reduced total taste score, particularly for 249 sweet and salty taste, in patients with objective dry mouth (measured by the friction with mirror 250 and dry tongue tests). Low sum score for salty taste was also related to low stimulated salivary 251 flow rate. The rest of the studies evaluated taste ability through global questionnaires including 252 self-assessed items on oral function, with contradictory results. Two studies $(30 ; 35)$ found that 253 hyposalivation was negatively and significantly correlated to self-assessed taste satisfaction, 
254 whilst Yoshinaka and coworkers (2007)(29) failed to find this correlation. In addition to the 255 measure of salivary flow rate, Ikebe et al., (2002)(30) measured the $\mathrm{pH}$ of the stimulated saliva 256 but no correlation between the $\mathrm{pH}$ and taste satisfaction could be established.

257 In summary, most of the studies on this topic have shown a relationship between a reduced 258 salivary function and alterations in food oral processing (mastication, swallowing, orosensory 259 perception). It should be noted that this relationship seems clearer when the outcomes were 260 measured objectively rather than by questionnaires.

\section{3.6. Association between salivary hypofunction and food behavior (4 studies)}

262 Two studies $(36 ; 37)$ examined the possible relationship between hyposalivation and appetite, 263 and two others between hyposalivation and dietary intake $(25 ; 31)$. For both categories, the 264 outcomes were evaluated throughout the use of four different questionnaires: a questionnaire related to dietary intakes/nutrition and masticatory function (36), a single question-item on appetite (37); a 3-day record on food intake (31); a brief-type self-administered diet history

267 questionnaire (25). The use of questionnaires could be justified by the fact that appetite is the subjective desire of eating foods. In 1999, Dormenval and coworkers(36) found that lack of appetite was associated with hyposalivation (stimulated salivary flow rate $<0.5 \mathrm{ml} / \mathrm{min}$ ) in

270 hospitalized Swiss patients. More recently, Samnieng (2014)(37) also found a positive 271 correlation between lack of appetite and low resting salivary flow in independently living older 272 Norwegians.

273 Regarding dietary intake, the two selected studies found no association between total energy 274 intake and hyposalivation. However, when studying specific nutrient and food intake, Iwasaki 275 and collaborators (2016)(25) found that the hyposalivation group had significantly lower intake 276 of n-3 poly-unsaturated fatty acids, potassium, vit E, D, B6 and folate, which was in line with 
277 the observed reduction in the consumption of vegetables, fish and shellfish. Moreover, mean 278 dietary intake of protein and vitamin B12 in the hyposalivation group tended to be lower than 279 in the control group $(0.05<P<0.10)$.

280 In summary, the scarce literature available on this topic showed an association between 281 hyposalivation and appetite loss and unbalanced dietary intake in elderly people.

\subsection{Association between salivary hypofunction and nutritional status (7 studies)}

283 The association between salivary gland hypofunction and nutritional status has been evaluated 284 in 7 studies. Five of them $(26 ; 28 ; 35 ; 38 ; 39)$ evaluated the nutritional status using the Mini 285 Nutritional Assessment (MNA). Meanwhile, Dormenval and coworkers, (1998) (40) assessed 286 the nutritional status by quantifying biological malnutrition markers (BMI, level of serum 287 albumin) and anthropometric measurements. Finally, Poisson et al., (2014) (31) employed both 288 the MNA and the values of serum albumin concentration.

289 The results showed that hyposalivation was significantly associated with malnutrition in 4 290 studies $(26 ; 35 ; 39 ; 40)$. Additionally, Syrjälä and co-workers (2013)(38) showed that subjects 291 with low salivary flow (at rest or under stimulation) were slightly more at risk of malnutrition 292 than subjects with normal salivary flow though their results were not statistically significant. 293 Besides, Soini et al., (2003)(28) stated that no relation was found between hyposalivation and 294 malnutrition. However, they found a significant association between the clinical dentist 295 evaluation of dry mouth and the risk of malnutrition $(\mathrm{p}=0.049)$. On the contrary, Poisson and 296 coauthors (2014)(31) did not find any relationship between hyposalivation (determined as 297 salivary flow under the tongue $<0.1 \mathrm{~g} / \mathrm{min}$ ) and MNA and/or biological malnutrition either at 298 univariate or multivariate level. In addition to the measure of salivary flow rate, Srinivasulu et al., (2014)(39) measured the $\mathrm{pH}$, the buffer capacity, the total protein and the total calcium of 
saliva samples. However, the authors did not highlight any significant correlation between the

301 saliva composition and nutritional status.

302 In summary, five studies found a correlation between hyposalivation and malnutrition. Another study observed a relationship between the objective evaluation of dry mouth and the risk of malnutrition. Only one article did not find any association between the two variables. Therefore, and although most of the studies have shown some associations between salivary hypofunction 306 and nutritional status, up to date this relationship is still controversial.

\section{Discussion}

Salivary hypofunction refers to alterations in the quality (composition) or quantity (salivary

309 flow, residual saliva in the mouth) of saliva secreted into the human mouth (41). This situation

310 could alter the orosensory perception while eating, which is one of the most recognized

311 determinants for consumer's preferences and food consumption (7). As a result, the appetite,

312 dietary intake and nutritional status of an individual could be compromised. This is of special

313 relevance for elderly people, a population group frequently affected by both salivary and

314 nutritional deficiencies. The aim of this work was to systematically review all the existing

315 papers on this topic, in order to explore the relationships between a reduced salivary output and

316 food consumption in the elderlies. In this paper only objective measurements of salivary

317 hypofunction were considered, since the subjective complaint of dry mouth (xerostomia) is not

318 always associated with an objective evidence of reduced salivary secretions $(20 ; 42)$.

319 In total, 15 articles met the criteria for inclusion in this work (see Table 1). Eight of them studied

320 the relationship of salivary hypofunction with food oral processing, 2 with appetite, 2 with

321 dietary intake and 7 with nutritional status. In general, the selected studies clearly showed some

322 associations between salivary hypofunction and the studied parameters. However, some 
controversial results have also been observed. It should also be noticed that the study

324 characteristics are very different from one study to another, and the presence of not controlled confounding factors or methodological issues should be taken into account to interpret the results.

\section{Discussion on the methods used to measure salivary hypofunction}

This review focuses on studies that objectively measured symptoms of salivary hypofunction. The prevalence of the population suffering these symptoms ranged from $14 \%$ (35) to around $50 \%(26 ; 28)$ in the selected articles. These differences were most likely dependent to the different characteristics of the studied populations (such as age, race, living place (community, institutions, and hospitals), functional status (healthy $v s$ ill), drugs consumption, etc.) but also on the methods and cut-off values employed to determine salivary hypofunction.

For most of the selected studies (14 out of 15), the determination of the salivary flow below a cut-off value was the tool used to determine salivary hypofunction (see Table 3). However, a lack of consensus was observed regarding the type of saliva collected (at rest or under stimulation), the protocol employed to measure the salivary flow rate (spitting, draining method, cotton roll), and the cut-off value to determine hyposalivation. Of the 14 studies that measured saliva flow, five of them performed both resting and stimulated measurements (28; $35 ; 36 ; 38 ; 40)$, seven studies based their results on the measure of stimulated salivary flow (25; $26 ; 27 ; 29 ; 30 ; 34 ; 39)$, one study only measured the resting salivary flow rate $(37)$ whilst one study performed the measure of salivary flow under the tongue (31). The use of resting or stimulated salivary flow rates provides different information since saliva is not delivered to the human mouth by the same salivary glands and in the same proportions under the two conditions. Therefore, whole saliva at rest, where the submandibular gland predominates, differs from that secreted during stimulation (more related to parotid gland function). Consequently, and in spite 
347 of the scarce literature on this topic, it is not surprising that the two measures are not always 348 correlated (43).

349 Moreover, two studies used additional methods (dentist evaluation, mirror test and tongue 350 moisture) to measure salivary hypofunction besides the determination of the salivary flow (27; 351 28). These methods could show a more advance phase of salivary hypofunction where the oral 352 integrity (mucosa, tongue) has already been affected due to a prolonged hyposalivation situation 353 held over time. In addition, only two studies $(30 ; 39)$ reported, additionally to the measure of 354 stimulated salivary flow, changes in saliva composition. This could be due to the fact that these 355 analyses are time consuming and expensive, and therefore difficult to be performed to study 356 big populations, as those employed in the selected articles.

357 Otherwise, one study (32) did not use the measure of salivary flow to determine salivary 358 hypofunction but evaluated it by measuring the moisture of the buccal mucosa. The device used 359 for this evaluation determined the weight percentage of water found in the mucosa. Originally 360 developed to measure the moisture of the skin, the device was modified specifically for this 361 study. As it is not a common method used to measure hyposalivation, it is not possible to 362 compare the results of this study to the results of the other selected studies.

363 In addition to the different parameters employed to determine hyposalivation (salivary flow at 364 rest or under stimulation, moisture of mucosa, etc), within the same parameter, the protocol was 365 not always performed in the same way. Table 3 highlights the differences observed in collection 366 times (from 1 to 6 minutes), hours of collection (respecting or not the circadian rhythms), 367 collection protocols (free spitting vs controlled), etc., employed to measure salivary 368 hypofunction. Moreover, only three articles $(32 ; 36 ; 40)$ measured the selected parameters two 369 or three times, whilst the other studies only performed the measures once. Therefore, no 
information about the accuracy of the methods could be obtained, that in the worst scenario

371 could be traduced in a misclassification of people across the groups.

372 The cut-off value to determine salivary hypofunction was consensual across the studies for the 373 saliva at rest. A value lower than $0.1 \mathrm{ml} / \mathrm{min}$ was considered hyposalivation. However for the 374 salivary flow under stimulation a high dispersion on the cut-off values was encountered among 375 studies. Indeed, there is no universally accepted reference value to determine hyposalivation 376 using stimulated salivary flow rate. Most of the authors employed a cut-off value of $0.5 \mathrm{ml} / \mathrm{min}$ 377 to define hyposalivation $(25 ; 26 ; 29 ; 34 ; 35 ; 36 ; 40)$, whilst others employed values ranged from 0.5 to $1 \mathrm{ml} / \mathrm{min}(27 ; 38)$. The differences in the cut-off points could derive in an erroneous assignation of the participants to the groups and in a misinterpretation of the results, making 380 difficult the comparison of the studies. This was displayed in the study of Mesas et al., (2010) 381 (26). Authors employed two cut-off levels (stimulated salivary flow rate $<0.5$ and stimulated 382 salivary flow rate $<0.7 \mathrm{ml} / \mathrm{min}$ ) to define hyposalivation, and they only found a significant 383 association with nutritional status when using the value of $0.7 \mathrm{ml} / \mathrm{min}$. For the other methods employed to define salivary hypofunction, like the "mirror test" and dry tongue methods, the comparison across studies is difficult because they are less frequently employed and dependent on the dentist's criteria. The moisture of oral mucosa cannot be either compared since the 387 method was only employed in one article.

388 All these remarks highlight the idea that the diagnosis of salivary hypofunction is not consensual across the studies. Therefore, guidelines to measure salivary flow hypofunction with 390 one or several complementary methods to evaluate the degree of dysfunction would be 391 appropriate to allow an international standardization and a better comparison across the studies.

392 Moreover longitudinal studies observing secretory function over time are required to establish 393 causality. This would acknowledge setting up normal ranges or cut-off points to distinguish 
normal from abnormal salivary function. That amount is probably different across cultures

395 (depending on gland sizes) (44).

396 412 results were controversial $(31 ; 32)$.

413 In spite of chemosensory perception is a key factor for food enjoyment and one of the factors 414 that motivate food consumption, its association with salivary gland hypofunction in the elderlies 415 have received little attention. This could be due to the fact that food science has historically 416 focused on the food and only in the later years some research groups have started to consider

\section{Figure 2 about here}

As can be seen in Figure 2, salivary hypofunction was related to food oral processing, and in particular to mastication. It has been shown that elderly with hyposalivation had a reduced ability to break down foods into discrete portions by chewing to permit swallowing (34). This effect was more important in denture wearers with a lack of posterior occlusal contacts. Moreover, a relationship between hyposalivation and poor self-assessed chewing ability has been shown in four articles. Authors suggested that although presenting an altered masticatory performance is a multifactorial problem, salivary flow is a critical factor for masticatory function. However, the associations with dysphagia or swallowing have been less studied and 
417 the interaction between food and human physiology to explain food perception. Moreover, to 418 date most of the studies regarding the relation between the role of saliva on flavor release and 419 perception have been conducted on healthy and young individuals ( $<65 \mathrm{y} / \mathrm{o})$, while elderly 420 population remains underexplored. Therefore only 4 articles met the inclusion criteria and they 421 were all based on taste. While it has been found that salivary hypofunction is related to the 422 objectively measured taste perception $(27 ; 45)$, for the self-assessed taste ability results are controversial. However, most epidemiological studies do not include objective measurements of taste perception, probably because the evaluation through tests is more time-consuming than performing questionnaires.

To the author's knowledge the association between hyposalivation and texture or other

427 modalities of orosensory perception (e.g aroma) in the elderlies has not been addressed by the 428 scientific community yet. Some studies reported age-related loss of texture sensation $(46 ; 47)$ and ultimately texture preference changes (48), but these studies have not investigated the role of a diminished saliva secretion in the observed results.

431 Assuming that a reduced salivary output produces an impaired food experience, the desire for 432 food or drink known as appetite could be altered. This is in agreement with the findings of the 433 two selected articles on this topic which shown a relationship between hyposalivation and loss 434 of appetite $(37 ; 40)$, even when the settings employed were very different in both of them. 435 Consequently, this appetite loss could provoke a diminished food intake. However, the two 436 studies on this topic found that the total energy intake was not impaired in elderly with 437 hyposalivation. Nevertheless, when specific nutrients and/or group of foods were studied, the 438 hyposalivator group presented a reduced consumption of vegetables, fish and seafood which 439 was related to the lower intake of n-3 polyunsaturated fatty acids, potassium, vit C, E, B6 and 440 folate after adjusting for confounders (number of teeth, denture use, sex, income, education, 
441 body mass index, smoking status, alcohol use, diabetes, medication, activities of daily living, 442 depression and total calorie intake) (25). A reduced consumption of such specific nutriments/or 443 groups of food, which are recognized for their health benefits $(49 ; 50 ; 51)$, could have a negative 444 impact on the health of this population.

445 Finally, an alteration of the dietary intake (quantitative or qualitative) could provoke an 446 impairment of the nutritional status of the elderly population. Numerous studies have been 447 conducted during the last decade to study the relationship between nutritional status and oral 448 conditions in elderly, but to the authors' knowledge, only 7 studies have assessed the 449 relationship between salivary hypofunction and nutritional status. However, some contradictory 450 results have been found. While four articles found a significant correlation between MNA and 451 hyposalivation, one did not. Although the method used to measure salivary flow was similar in 452 the five studies, the cut-off values differed among them, which could explain the differences 453 found in their results. On the other hand, the other two selected articles $(28 ; 38)$ encountered 454 only weak associations between nutritional status and hyposalivation or the dentist's estimation 455 of dry mouth. Although other reasons (different cut-off levels, circadian rhythms not controlled, 456 differences across populations) could explain these differences, it is interesting to observe that 457 in these last two studies none of the subjects were malnourished but at risk of malnutrition. This 458 is of importance since probably nutritional disturbances held over time can cause atrophy of 459 salivary glands (39), producing a reduction of their function. If this is truth, alterations on saliva 460 would be a consequence of an altered nutritional status. Unfortunately, as all the selected studies 461 presented a cross sectional design no causality could be established and more studies are needed 462 to validate this hypothesis.

463 Finally, the measure of the food consumption parameters was mostly performed by using 464 subjective than objective methods. This could be due to the fact that the use of self-report 
465

questionnaires is less time consuming than performing objective determinations. However, as many studies have shown no correlation between the subjective feeling of dry mouth (xerostomia) and hyposalivation, there are no evidences of links between objective and subjective evaluations of the outcomes (29).

\section{Limitations and strengths of the present SLR}

The main strength of this work is that it is a solid literature search, with a complete overview of the relationship between an objective measurement of salivary hypofunction and the determinants of food consumption among the elderly population. Moreover, the selected studies represent the wide heterogeneity found in this population group (from healthy elderly individuals to chronically ill hospitalized old-people). The analysis of the quality of the selected articles let us to identify the most frequent risks across the studies and suggest new ideas for future works. For example, future studies on this topic should control better for confounding factors like gender, age, drug intake, diseases, mental status, socioeconomic status, dental status and place to live, because they are well-known factors that can alter salivary function $(52 ; 53$; $54 ; 55 ; 56 ; 57 ; 58)$.

However, this study presents some limitations. Unfortunately, we were not able to perform a meta-analysis due to the obvious heterogeneity among the studies in relation to definitions and measurements as explained above. Also, we could not establish causality due to the crosssectional nature of the selected studies. Therefore it cannot be concluded if hyposalivation is a cause or a consequence of the selected food consumption parameters.

\section{Implication of this study}

The implications for research of this study are: firstly, the need to introduce and implement universal guidelines to assess salivary hypofunction; secondly, the necessity of performing 


\section{Acknowledgments}

\section{Conclusions} [ANR-14-CE20-0001-01].

cohort studies with comparable groups following the same population for a longer period of time and statistical control of the confounding factors to establish causality.

The main findings of this review can be summarized in the following points: 1) to date, salivary hypofunction is mainly based on measures of salivary flow 2) definition and measures of hyposalivation are different across the studies; 3) salivary hypofunction has been related to a decrease of objective chewing and swallowing abilities and taste perception; very little is known about other modalities of chemosensory perception (e.g. aroma) 4) hyposalivation has been associated with appetite loss; 5) hyposalivation has been related to an unbalanced dietary intake but not with total intake; 6) it has been seen a relationship between saliva deficiencies and malnutrition, though some controversial results have also been shown. Although it is not possible to completely eliminate the potential effects of underlying methodological issues and in spite of the scarce number of publications on this topic it is suggested a relationship between salivary hypofunction and food consumption in the elderlies. Unfortunately, due to the crosssectional nature of the articles, no causality could be established. Therefore longitudinal studies on this topic controlling for confounding factors are needed.

CMG thanks the support of the Agreenskills fellowship program which has received funding from the EU's Seventh Framework Program under grant agreement $N^{\circ}$ FP7-609398 (AgreenSkills + contract). Authors thank the French National Research Agency for financial support through the AlimaSSenS project [ANR-14-CE20-0003-01] and the MuFFIn project 


\section{References}

512 (1) Mese H, Matsuo R. (2007). Salivary secretion, taste and hyposalivation. J Oral Rehabil, 34, 711-723.

514

(2) Mandel I D. (1989). The role of saliva in maintaining oral homeostasis. J Am Dental Assoc, 119, 298-304.

(3) Loesche W J, Schork A, Terpenning M S, Chen Y M, Stoll J. (1995). Factors which influence levels of selected organisms in saliva of older individuals. J Clin Microb, 33, 2550-2557.

(4) Caplan D J, Hunt R J. (1996). Salivary flow and risk of tooth loss in an elderly population. Commun Dent Oral Epidemiol, 24, 68-71.

(6) Prinz J F, Lucas P W. (1997). An optimization model for mastication and swallowing in mammals. Proceed Royal Society B-Biol Sci, 264, 1715-1721.

(7) Buettner A. (2002). Influence of human saliva on odorant concentrations. 2. aldehydes, alcohols, 3-alkyl-2-methoxypyrazines, methoxyphenols, and 3-hydroxy-4,5-dimethyl2(5H)-furanone. J Agric Food Chem, 50, 7105-7110.

Narhi T O, Kurki N, Ainamo A. (1999). Saliva, salivary micro-organisms, and oral health in the home-dwelling old elderly - A five-year longitudinal study. J Dent Res, 78, 1640-1646.

(10) Sreebny L M, Schwartz S S. (1986). A reference guide to drugs and dry mouth. Gerodontology, 5, 75-99.

(11) Affoo R H, Foley N, Garrick R, Siqueira W L, Martin R E. (2015). Meta-Analysis of Salivary Flow Rates in Young and Older Adults. J Am Geriatr Soc, 63, 2142-2151.

(12) Vandenberghe-Descamps M, Laboure H, Prot A, Septier C, Tournier C, Feron G, Sulmont-Rosse C. (2016). Salivary flow decreases in healthy elderly people independently of dental status and drug intake. J Texture St, 47, 353-360.

(13) Mowe M, Bohmer T, Kindt E. (1994). Reduced nutritional-status in an elderly population (greater-than-70y) is probable before disease and possibly contributes to the development of disease. Am J Clin Nut, 59, 317-324. 
(14) McWhirter J P, Pennington C R, Jebb S A. (1994). Incidence and recognition of malnutrition in-hospital. Clin Nut, 13, 267-268.

(15) Quandt S A, Chen H Y, Bell R A, Savoca M R, Anderson A M, Leng X Y, Kohrman T, Gilbert G H, Arcury T A. (2010). Food Avoidance and Food Modification Practices of Older Rural Adults: Association With Oral Health Status and Implications for Service Provision. Gerontologist, 50, 100-111.

(16) Quandt S A, Savoca M R, Leng X Y, Chen H Y, Bell R A, Gilbert G H, Anderson A M, Kohrman T, Arcury T A. (2011). Dry Mouth and Dietary Quality in Older Adults in North Carolina. J Am Geriatr Soc, 59, 439-445.

(17) Stenman U, Ahlqwist M, Bjorkelund C, Hakeberg M. (2012). Oral health-related quality of life - associations with oral health and conditions in Swedish 70-year-old individuals. Gerodontology, 29, E440-E446.

(18) Nykanen I, Lonnroos E, Kautiainen H, Sulkava R, Hartikainen S. (2013). Nutritional screening in a population-based cohort of community-dwelling older people. Eur $\mathbf{J}$ Public Health, 23, 405-409.

(19) Porter J, Ntouva A, Read A, Murdoch M, Ola D, Tsakos G. (2015). The impact of oral health on the quality of life of nursing home residents. HQLF, 13.

(20) Narhi T O, Meurman J H, Ainamo A. (1999). Xerostomia and hyposalivation - Causes, consequences and treatment in the elderly. Drugs Aging, 15, 103-116.

(21) Ohara Y, Hirano H, Yoshida H, Obuchi S, Ihara K, Fujiwara Y, Mataki S. (2016). Prevalence and factors associated with xerostomia and hyposalivation among community-dwelling older people in Japan. Gerodontology, 33, 20-27.

(22) Kmet L M, Robert C. Lee, and Linda S. Cook. (2004). Standard quality assessment criteria for evaluating primary research papers from a variety of fields.

(23) Satoh-Kuriwada S, Sasano, T., Saito, M., Hasimoto, K., Simeno, Y., Oba, M., Sakamoto, M., Aizawa, K. and Watanabe, M. (2003). Epidemiological study on taste disorders in the elderly. Part 1: Influence of systemic disease and medication on gustatory disorder. Jpn. J. Oral Diag. Oral Med., 16, 1-8.

(24) Satoh-Kuriwada S, Sasano, T., Saito, M., Simeno, Y., Oba, M., Sakamoto, M., Aizawa, K. and Watanabe, M. (2005). Epidemiological study on gus- tatory disorders in the elderly. Part 2: Influence of hyposalivation on gustatory disorder. Jpn. J. Oral Diag. Oral Med., 18, 14-18. 
(25) Iwasaki M, Yoshihara A, Ito K, Sato M, Minagawa K, Muramatsu K, Watanabe R, Manz M C, Ansai T, Miyazaki H. (2016). Hyposalivation and dietary nutrient intake among community-based older Japanese. Geriatr Gerontol Int, 16, 500-507.

(26) Mesas A E, Andrade S M, Cabrera M A, Bueno V L. (2010). Oral health status and nutritional deficit in noninstitutionalized older adults in Londrina, Brazil. Rev Bras Epidemiol, 13, 434-445.

(27) Solemdal K, Sandvik L, Willumsen T, Mowe M, Hummel T. (2012). The impact of oral health on taste ability in acutely hospitalized elderly. PLoS One, 7, e36557.

(28) Soini H, Routasalo P, Lauri S, Ainamo A. (2003). Oral and nutritional status in frail elderly. Spec Care Dentist, 23, 209-215.

(29) Yoshinaka M, Yoshinaka M F, Ikebe K, Shimanuki Y, Nokubi T. (2007). Factors associated with taste dissatisfaction in the elderly. J Oral Rehabil, 34, 497-502.

(30) Ikebe K, Sajima H, Kobayashi S, Hata K, Morii K, Nokubi T, Ettinger R L. (2002). Association of salivary flow rate with oral function in a sample of community-dwelling older adults in Japan. Oral Surg Oral Med Oral Pathol Oral Radiol Endod, 94, 184-190.

(31) Poisson P, Laffond T, Campos S, Dupuis V, Bourdel-Marchasson I. (2014). Relationships between oral health, dysphagia and undernutrition in hospitalised elderly patients. Gerodontology, 33, 161-168.

(32) Shinkawa T, Hayashida N, Mori K, Washio K, Hashiguchi K, Taira Y, Morishita M, Takamura N. (2009). Poor chewing ability is associated with lower mucosal moisture in elderly individuals. Tohoku J Exp Med, 219, 263-267.

(33) Yamada H, Nakagawa Y, Nomura Y, Yamamoto K, Suzuki M, Watanabe N Y, Saito I, Seto K. (2005). Preliminary results of moisture checker for Mucus in diagnosing dry mouth. Oral Dis, 11, 405-407.

(34) Ikebe K, Matsuda K, Morii K, Furuya-Yoshinaka M, Nokubi T, Renner R P. (2006). Association of masticatory performance with age, posterior occlusal contacts, occlusal force, and salivary flow in older adults. Int J Prosthodont, 19, 475-481.

(35) Samnieng P, Ueno M, Shinada K, Zaitsu T, Wright F A, Kawaguchi Y. (2012). Association of hyposalivation with oral function, nutrition and oral health in community-dwelling elderly Thai. Community Dent Health, 29, 117-123.

(36) Dormenval V, Mojon P, Budtz-Jorgensen E. (1999). Associations between self-assessed masticatory ability, nutritional status, prosthetic status and salivary flow rate in hospitalized elders. Oral Dis, 5, 32-38. 
(37) Samnieng P. (2014). Appetite loss and related factors in community-dwelling elderly thai. Int. J Clin. Prev. Dent., 10, 23-30.

(38) Syrjala A M, Pussinen P I, Komulainen K, Nykanen I, Knuuttila M, Ruoppi P, Hartikainen S, Sulkava R, Ylostalo P. (2013). Salivary flow rate and risk of malnutrition - a study among dentate, community-dwelling older people. Gerodontology, 30, 270275.

(39) Srinivasulu G, Fareed, N., Sudhir, K.M., Kumar, K. (2014). Relationship between Stimulated Salivary Factors, Dental Caries Status and Nutritional Condition among Institutionalized Elderly People. OHDM, 13, 49-53.

(40) Dormenval V, Budtz-Jorgensen E, Mojon P, Bruyere A, Rapin C H. (1998). Associations between malnutrition, poor general health and oral dryness in hospitalized elderly patients. Age Ageing, 27, 123-128.

(41) Glore R J, Spiteri-Staines K, Paleri V. (2009). A patient with dry mouth. Clinical Otolaryngology, 34, 358-363.

(42) Villa A, Abati S. (2011). Risk factors and symptoms associated with xerostomia: a cross-sectional study. Aust Dent J, 56, 290-295.

(43) Neyraud E, Palicki O, Schwartz C, Nicklaus S, Feron G. (2012). Variability of human saliva composition: Possible relationships with fat perception and liking. Arch Oral Biol, 57, 556-566.

(44) Ship J A, Fox P C, Baum B J. (1991). How much saliva is enough - normal function defined. J Am Dental Assoc, 122, 63-69.

(45) Satoh-Kuriwada S, Shoji N, Kawai M, Uneyama H, Kaneta N, Sasano T. (2009). Hyposalivation Strongly Influences Hypogeusia in the Elderly. J Health Sci, 55, 689698.

(46) Kremer S, Bult J H F, Mojet J, Kroeze J H A. (2007). Compensation for age-associated chemosensory losses and its effect on the pleasantness of a custard dessert and a tomato drink. Appetite, 48, 96-103.

(47) Kremer S, Mojet J, Kroeze J H A. (2005). Perception of texture and flavor in soups by elderly and young subjects. J Texture St, 36, 255-272.

(48) Forde C G, Delahunty C M. (2002). Examination of chemical irritation and textural influence on food preferences in two age cohorts using complex food systems. Food Qual Pref, 13, 571-581. 
(49) Carr A C, Frei B. (1999). Toward a new recommended dietary allowance for vitamin C based on antioxidant and health effects in humans. Am J Clin Nut, 69, 1086-1107.

(50) Lemaitre R N, King I B, Mozaffarian D, Kuller L H, Tracy R P, Siscovick D S. (2003). n-3 polyunsaturated fatty acids, fatal ischemic heart disease, and nonfatal myocardial infarction in older adults: the Cardiovascular Health Study. Am J Clin Nut, 77, 319-325.

(51) Rimm E B, Willett W C, Hu F B, Sampson L, Colditz G A, Manson J E, Hennekens C, Stampfer M J. (1998). Folate and vitamin B-6 from diet and supplements in relation to risk of coronary heart disease among women. JAMA, 279, 359-364.

(52) Bardow A, Nyvad B, Nauntofte B. (2001). Relationships between medication intake, complaints of dry mouth, salivary flow rate and composition, and the rate of tooth demineralization in situ. Arch Oral Biol, 46, 413-423.

(53) Kreher J M, Graser G N, Handelman S L. (1987). The relationship of drug-use to denture function and saliva flow-rate in a geriatric population. J Prosthetic Dent, 57, 631-638.

(54) Ship J A, Baum B J. (1990). Is reduced salivary flow normal in old-people. Lancet, 336, 1507-1507.

(55) Ship J A, Decarli C, Friedland R P, Baum B J. (1990). Diminished submandibular salivary flow in dementia of the alzheimer type. J Gerontology, 45, M61-M66.

(56) Caplan D J, Hunt R J. (1996). Salivary flow and risk of tooth loss in an elderly population. Community Dent Oral Epidemiol, 24, 68-71.

(57) Glazar I, Urek M M, Kuis D, Prpic J, Miskovic I, Pavicic D K, Pezelj-Ribaric S. (2016). Salivary flow rate, oral yeast colonization and dental status in institutionalized and noninstitutionalized elderly. Acta Clin Croatica, 55, 390-395.

(58) Percival R S, Challacombe S J, Marsh P D. (1994). Flow-rates of resting whole and stimulated parotid-saliva in relation to age and gender. J Dent Res, 73, 1416-1420.

(59) Sreebny L M, Yu A, Green A, Valdini A. (1992). Xerostomia in diabetes-mellitus. Diabetes Care, 15, 900-904.

(60) Flink H, Bergdahl M, Tegelberg A, Rosenblad A, Lagerlof F. (2008). Prevalence of hyposalivation in relation to general health, body mass index and remaining teeth in different age groups of adults. Community Dent Oral Epidemiol, 36, 523-531.

(61) Hirotomi T, Yoshihara A, Ogawa H, Ito K, Igarashi A, Miyazaki H. (2006). A preliminary study on the relationship between stimulated saliva and periodontal conditions in community-dwelling elderly people. J Dent, 34, 692-698. 
672 (62) Sreebny L M, Zhu W T. (1996). Anti-SS-A and anti-SS-B Ab's in the saliva and blood of patients with dry mouth and dry eyes. J Dent Res, 75, 2031-2031.

674 (63) Michael E C D, Denis O. (2004). Saliva and oral health. London.

675 (64) Cabrera M A S, Mesas A E, Rossato L A, De Andrade S M. (2007). Salivary flow and psychoactive drug consumption in elderly people. Revista Da Associacao Medica Brasileira, 53, 178-181.

678 (65) Narhi T O, Tenovuo J, Ainamo A, Vilja P. (1994). Antimicrobial factors, sialic-acid, and protein-concentration in whole saliva of the elderly. Scand J Dent Res, 102, 120125.

(66) Henricsson V, Svensson A, Axell T. (1990). Evaluation of some electrical methods for objective assessment of oral mucosal dryness. Scand J Dent Res, 98, 520-528.

(67) Navazesh M. (1993). Methods for collecting saliva. Annals of the New York Academy of Sciences, 694, 72-77.

(68) Navazesh M, Kumar S K S. (2008). Measuring salivary flow - Challenges and opportunities. Journal of the American Dental Association, 139, 35S-40S.

(69) Osterberg T, Landahl S, Hedegard B. (1984). Salivary flow, saliva, ph and buffering capacity in 70-year-old men and women - correlation to dental-health, dryness in the 690 mouth, disease and drug-treatment. J Oral Rehabil, 11, 157-170. 


\begin{tabular}{|c|c|c|c|c|c|c|}
\hline Reference & \begin{tabular}{|c|} 
Study \\
design*
\end{tabular} & Study population & Country & $\begin{array}{l}\text { Functiona } \\
1 \text { status** } \\
\end{array}$ & $\begin{array}{l}\text { Parameter studied and } \\
\operatorname{method}(\mathrm{s})\end{array}$ & Results \\
\hline $\begin{array}{l}\text { Dormenval et } \\
\text { al., } 1998\end{array}$ & CS & $\begin{array}{c}\text { sample size: } 99 \\
\text { mean age } \pm \text { SD (years) } 82.5 \pm \\
4.0 \\
\text { gender (\% female): } 70\end{array}$ & Switzerland & $\mathrm{H}$ & $\begin{array}{l}\text { Nutritional status: } \\
\text { Anthropometric (BMI, } \\
\text { triceps skinfold thickness } \\
\text { and mid-arm } \\
\text { circumference), and } \\
\text { biological measurements } \\
\text { (serum albumin } \\
\text { concentration) } \\
\end{array}$ & $\begin{array}{l}\text { A low unstimulated salivary flow }(<0.1 \mathrm{ml} / \mathrm{min}) \text { was } \\
\text { associated with a BMI }<21 \text {, a severe malnutrition according } \\
\text { to triceps skinfold thickness }(\mathrm{P}<0,05) \text { and mid-arm } \\
\text { circumference }(\mathrm{P}<0,05) \text {. } \\
\text { A low stimulated salivary flow }(<0,5 \mathrm{ml} / \mathrm{min}) \text { was } \\
\text { associated with severe malnutrition according to triceps } \\
\text { skinfold thickness }(\mathrm{P}=0,01) \text {, mid-arm circumference }(\mathrm{P}< \\
0,05) \text {, and the serum albumin concentration }(\mathrm{P}=0,01) \text {. }\end{array}$ \\
\hline $\begin{array}{l}\text { Dormenval et } \\
\text { al., } 1999\end{array}$ & CS & $\begin{array}{c}\text { sample size: } 99 \\
\text { mean age } \pm \mathrm{SD}(\mathrm{y} / \mathrm{o}): 82.5 \pm 4.0 \\
\text { gender }(\% \text { female }): 70\end{array}$ & Switzerland & $\mathrm{H}$ & Appetite: questionnaire & $\begin{array}{l}\text { Lack of appetite was associated with a stimulated salivary } \\
\text { flow }<0,5 \mathrm{ml} \text { min- } 1 \quad(\mathrm{P}=0,05)\end{array}$ \\
\hline $\begin{array}{l}\text { Samnieng et } \\
\text { al., } 2012\end{array}$ & $\mathrm{CS}$ & $\begin{array}{c}\text { sample size: } 612 \\
\text { mean age } \pm \mathrm{SD}(\mathrm{y} / \mathrm{o}): 68.8 \pm 5.9 \\
\text { gender }(\% \text { female): } 74\end{array}$ & Thailand & $\mathrm{C}$ & $\begin{array}{l}\text { i) Oral function (tasting, } \\
\text { speaking, swallowing, } \\
\text { chewing): questionnaire } \\
\text { ii) Nutritional status: } \\
\text { MNA }\end{array}$ & $\begin{array}{l}\text { Hyposalivation in both edentate and edentulous subjects } \\
\text { was significantly associated with tasting, speaking } \\
\text { swallowing and chewing difficulty. } \\
\text { The hyposalivation group had a lower mean MNA score } \\
\text { than the normal salivation group }(\mathrm{p}<0,05) \text {. }\end{array}$ \\
\hline $\begin{array}{l}\text { Syrjälä et al., } \\
\quad 2013\end{array}$ & CS & $\begin{array}{c}\text { sample size: } 157 \\
\text { mean age } \pm \mathrm{SD}(\mathrm{y} / \mathrm{o}): 79.2 \pm 3.6 \\
\text { gender }(\% \text { female }): 70\end{array}$ & Finland & $\mathrm{C}$ & $\begin{array}{l}\text { Nutritional status (risk of } \\
\text { malnutrition): MNA-SF }\end{array}$ & $\begin{array}{c}\text { Subjects with a low unstimulated salivary flow rate or } \\
\text { stimulated salivary flow rate, when compared with those } \\
\text { with normal salivary flow, were at slightly increased risk of } \\
\text { malnutrition (NS) }\end{array}$ \\
\hline $\begin{array}{l}\text { Samnieng, } \\
2014\end{array}$ & CS & $\begin{array}{c}\text { sample size: } 612 \\
\text { mean age } \pm \text { SD }(\mathrm{y} / \mathrm{o}): 68.8 \pm 5.9 \\
\text { gender }(\% \text { female }): 74\end{array}$ & Thailand & $\mathrm{C}$ & Appetite: questionnaire & $\begin{array}{c}\text { Subjects with appetite loss had significantly lower mean } \\
\text { number of the salivary flow rate than those with the normal } \\
\text { appetite }(\mathrm{p}<0,05)\end{array}$ \\
\hline $\begin{array}{l}\text { Iwasaki et al., } \\
\quad 2016\end{array}$ & $\mathrm{CS}$ & $\begin{array}{c}\text { sample size: } 352 \\
\text { mean age } \pm \mathrm{SD}(\mathrm{y} / \mathrm{o}): 80.0 \pm 0.0 \\
\text { gender }(\% \text { female): } 51\end{array}$ & Japan & $\mathrm{C}$ & $\begin{array}{l}\text { i)Dietary intake: } \\
\text { validated food frequency } \\
\text { questionnaire } \\
\text { ii) Subjective capacities } \\
\text { to eat and swallow: } \\
\text { questionnaire }\end{array}$ & $\begin{array}{l}\text { The hyposalivation group had significantly more self- } \\
\text { reported chewing ( } \mathrm{p}<0,001) \text { and swallowing }(\mathrm{p}<0,036) \\
\text { difficulties. The total energy intake was not different } \\
\text { between the two groups. The hyposalivation group had } \\
\text { significantly lower intake of } \mathrm{n}-3 \text { polyunsaturated fatty acid, } \\
\text { potassium, vitamin } \mathrm{D} \text {, vitamin } \mathrm{E} \text {, vitamin } \mathrm{B} 6 \text { and folate } \\
\text { than the group without hyposalivation }(\mathrm{P}<0,05) \text { after } \\
\text { adjusting for confounders. Vegetable, fish and shellfish }\end{array}$ \\
\hline
\end{tabular}




\begin{tabular}{|c|c|c|c|c|c|c|}
\hline & & & & & & $\begin{array}{l}\text { consumption was significantly lower in the hyposalivation } \\
\text { group }(\mathrm{P}<0,05) \text {. }\end{array}$ \\
\hline $\begin{array}{l}\text { Ikebe et al., } \\
2006\end{array}$ & $\mathrm{CS}$ & $\begin{array}{c}\text { sample size: } 328 \\
\text { mean age } \pm \text { SD }(y / o): 66.2 \pm 4.1 \\
\text { gender }(\% \text { female }): 47\end{array}$ & Japan & $\mathrm{C}$ & $\begin{array}{l}\text { Masticatory } \\
\text { performance: Gummy } \\
\text { jellies test }\end{array}$ & $\begin{array}{c}\text { Masticatory ability was significantly associated with } \\
\text { hyposalivation }(\mathrm{P}=0,006) \text { at bivariate and multivariate level } \\
(\mathrm{P}=0,046) \text { (after controlling with others variables). } \\
\text { When separating the subjects by the Eichner index (related } \\
\text { to number of posterior occlusal contacts of the natural } \\
\text { dentition), hyposalivation had a significant relationship } \\
\text { with masticatory performance in the group with no support } \\
\text { zone at all }(\mathrm{P}<0,003) \text { and the group with contact in } 1 \text { to } 3 \\
\text { zones }(\mathrm{P}=0,047) \text { but not in the group with contacts in } 4 \\
\text { support zones. }\end{array}$ \\
\hline $\begin{array}{l}\text { Yoshinaka et } \\
\text { al., } 2007\end{array}$ & $\mathrm{CS}$ & $\begin{array}{c}\text { sample size: } 640 \\
\text { mean age } \pm \mathrm{SD}(\mathrm{y} / \mathrm{o}): 66.0 \pm 4.2 \\
\text { gender }(\% \text { female }): 50\end{array}$ & Japan & $\mathrm{C}$ & $\begin{array}{l}\text { Subjective dissatisfaction } \\
\text { with taste ability: } \\
\text { questionnaire } \\
\end{array}$ & $\begin{array}{l}\text { No correlation was found between hyposalivation and } \\
\text { dissatisfaction with taste ability }\end{array}$ \\
\hline $\begin{array}{l}\text { Mesas et al., } \\
2010\end{array}$ & $\mathrm{CS}$ & $\begin{array}{c}\text { sample size: } 267 \\
\text { mean age } \pm \text { SD }(y / o): 66.5 \pm 4.1 \\
\text { gender }(\% \text { female }): 60\end{array}$ & Brazil & $\mathrm{C}$ & Nutritional status: MNA & $\begin{array}{c}\text { Hyposalivation (stimulated salivary flow }<0,5 \mathrm{ml} / \mathrm{min} \text { ) was } \\
\text { more frequent among participants with nutritional deficit, } \\
\text { even though there was no statistically negative association. } \\
\text { However, stimulated salivary flow }<0,7 \mathrm{ml} / \mathrm{min} \text { was } \\
\text { associated with nutritional deficit independently of adjusted } \\
\text { confounding factors. }\end{array}$ \\
\hline $\begin{array}{l}\text { Poisson et al., } \\
2014\end{array}$ & $\mathrm{CS}$ & $\begin{array}{l}\text { sample size : } 159 \\
\text { mean age } \pm \text { SD }(y / o): 85.3 \pm 5.7 \\
\text { gender }(\% \text { female }): 68\end{array}$ & France & $\mathrm{H}$ & $\begin{array}{l}\text { i) Dysphagia: swallowing } \\
\quad \text { abilities } \\
\text { ii) Nutritional status: } \\
\text { BMI, serum albumin } \\
\text { concentration, MNA-SF } \\
\text { iii) Dietary intake: } 3 \text {-day } \\
\quad \text { records }\end{array}$ & $\begin{array}{l}\text { Salivary hypofunction was related to dysphagia }(\mathrm{p}<0,001) \\
\text { at univariate level, but not to malnutrition. Low saliva flow } \\
\text { was not related to protein and energy intake. }\end{array}$ \\
\hline $\begin{array}{l}\text { Soini et al., } \\
\quad 2003\end{array}$ & $\mathrm{CS}$ & $\begin{array}{l}\text { sample size: } 51 \\
\text { mean age } \pm \text { SD }(y / o): 83.7 \pm 4.4 \\
\text { gender }(\% \text { female }): 78\end{array}$ & Finland & $\mathrm{C}$ & $\begin{array}{l}\text { Nutritional status (risk of } \\
\text { malnutrition): MNA }\end{array}$ & $\begin{array}{l}\text { Saliva secretion was not found to be related to the MNA, } \\
\text { but the clinical evaluation of dry mouth was related to the } \\
\text { risk of malnutrition }(\mathrm{p}=0,049) \text {. Subjects at risk of } \\
\text { malnutrition had as well a significantly more chewing and } \\
\text { swallowing problems }(\mathrm{p}=0,015) \text {. }\end{array}$ \\
\hline $\begin{array}{l}\text { Solemdal et } \\
\text { al., } 2012\end{array}$ & $\mathrm{CS}$ & $\begin{array}{c}\text { sample size: } 174 \\
\text { mean age } \pm \text { SD }(y / o): 83.5 \pm 6.1 \\
\text { gender }(\% \text { female }): 68\end{array}$ & Norway & $\mathrm{H}$ & $\begin{array}{l}\text { Taste ability: taste strips } \\
\text { method }\end{array}$ & $\begin{array}{l}\text { Total taste score, and particularly sweet and salty taste, } \\
\text { were significantly and markedly reduced in patients with } \\
\text { dry mouth. Furthermore, the salty sum score was positively }\end{array}$ \\
\hline
\end{tabular}




\begin{tabular}{|c|c|c|c|c|c|c|}
\hline & & & & & & $\begin{array}{c}\text { associated with a stimulated salivary flow }<0,6 \mathrm{~g} / \mathrm{min}(\mathrm{p}= \\
0,023) .\end{array}$ \\
\hline $\begin{array}{l}\text { Srinivasulu et } \\
\text { al } 2014\end{array}$ & $\mathrm{CS}$ & $\begin{array}{c}\text { sample size: } 81 \\
\text { mean age } \pm \text { SD }(\mathrm{y} / \mathrm{o}): 70.0 \pm 7.1 \\
\text { gender }(\% \text { female }): 58\end{array}$ & India & I & Nutritional status: MNA & $\begin{array}{c}\text { Salivary flow rate decreased among malnourished subjects } \\
(0,50 \pm 0,100) \text { when compared to well-nourished subjects } \\
(0,93 \pm 0,260) \text {. The other parameters (total protein content, } \\
\text { total calcium, pH, buffer capacity) were not statistically } \\
\text { significant }\end{array}$ \\
\hline $\begin{array}{l}\text { Ikebe et al., } \\
\quad 2002\end{array}$ & $\mathrm{CS}$ & $\begin{array}{c}\text { sample size: } 351 \\
\text { mean age } \pm \text { SD }(\mathrm{y} / \mathrm{o}): 66.7 \pm 4.3 \\
\text { gender }(\% \text { female }): 46\end{array}$ & Japan & $\mathrm{C}$ & $\begin{array}{l}\text { Dissatisfaction with } \\
\text { tasting; self-assessed } \\
\text { chewing ability: } \\
\text { questionnaire }\end{array}$ & $\begin{array}{l}\text { Hyposalivation (stimulated salivary flow }<0,5 \mathrm{ml} / \mathrm{min} \text { ) was } \\
\text { associated with dissatisfaction with tasting food }(\mathrm{P}<0,05) \\
\text { and self-assessed chewing ability }(\mathrm{NS}) \text {. } \\
\text { No correlation was found between pH of stimulated saliva } \\
\text { and oral function. }\end{array}$ \\
\hline $\begin{array}{l}\text { Shinkawa et } \\
\text { al, } 2009\end{array}$ & $\mathrm{CS}$ & $\begin{array}{c}\text { sample size: } 502 \\
\text { mean age } \pm \text { SD }(\mathrm{y} / \mathrm{o}): 72.3 \pm 6.7 \\
\text { gender }(\% \text { female }): 51\end{array}$ & Japan & $\mathrm{C}$ & $\begin{array}{c}\text { Satisfaction with } \\
\text { chewing and swallowing } \\
\text { abilities: questionnaire }\end{array}$ & $\begin{array}{l}\text { A lower mucosal moisture was significantly associated } \\
\text { with the subjective chewing ability but not with swallowing }\end{array}$ \\
\hline
\end{tabular}

* CS: cross-sectional studies

** C: community dwelling volunteers (independently living); I: Institutionalized volunteers; H: hospitalized patients 
Table 2. Quality assessment of the 15 selected studies

\begin{tabular}{|c|c|c|c|c|c|c|c|c|c|c|c|c|}
\hline Reference & $\begin{array}{l}\text { Question/ } \\
\text { objective } \\
\text { sufficiently } \\
\text { described? }\end{array}$ & $\begin{array}{c}\text { Study } \\
\text { design } \\
\text { evident } \\
\text { and } \\
\text { appropriate } \\
?\end{array}$ & $\begin{array}{c}\text { Method of } \\
\text { subject } \\
\text { selection is } \\
\text { described } \\
\text { and } \\
\text { appropriate } \\
?\end{array}$ & $\begin{array}{c}\text { Subject } \\
\text { characteristics } \\
\text { are } \\
\text { sufficiently } \\
\text { described? }\end{array}$ & $\begin{array}{c}\text { Outcome } \\
\text { measures(s) } \\
\text { well defined and } \\
\text { robust to } \\
\text { measurement/ } \\
\text { misclassificatio } \\
\mathrm{n} \text { bias? Means } \\
\text { of assessment } \\
\text { reported? }\end{array}$ & $\begin{array}{c}\text { Sample } \\
\text { size } \\
\text { appropriate } \\
?\end{array}$ & $\begin{array}{l}\text { Analytic } \\
\text { methods } \\
\text { described } \\
\text { /justified } \\
\text { and } \\
\text { appropria } \\
\text { te? }\end{array}$ & $\begin{array}{l}\text { Some } \\
\text { estimate } \\
\quad \text { of } \\
\text { variance } \\
\quad \text { is } \\
\text { reported } \\
\text { for main } \\
\text { results? }\end{array}$ & $\begin{array}{l}\text { Controlled for } \\
\text { confounding? } \\
\text { (age, gender, } \\
\text { drug intake, } \\
\text { diseases, } \\
\text { mental status, } \\
\text { socio- } \\
\text { economic } \\
\text { status, dental } \\
\text { status and } \\
\text { place to live) }\end{array}$ & $\begin{array}{l}\text { Results } \\
\text { reported } \\
\text { in } \\
\text { sufficient } \\
\text { detail? }\end{array}$ & $\begin{array}{l}\text { Conclusions } \\
\text { supported by } \\
\text { results? }\end{array}$ & $\begin{array}{l}\text { Sum } \\
\text { Score }\end{array}$ \\
\hline $\begin{array}{l}\text { Dormenval } \\
\text { et al., } 1998\end{array}$ & Yes & Yes & Yes & Yes & Yes & Yes & Yes & Yes & Partial & Partial & Yes & 0.91 \\
\hline $\begin{array}{l}\text { Dormenval } \\
\text { et al., } 1999 \\
\end{array}$ & Yes & Partial & Yes & Yes & Yes & Yes & Partial & Yes & Partial & Yes & Partial & 0.82 \\
\hline $\begin{array}{l}\text { Samnieng et } \\
\text { al., } 2012\end{array}$ & Yes & Yes & Yes & Yes & Yes & Yes & Yes & Yes & Partial & Yes & Yes & 0.95 \\
\hline $\begin{array}{l}\text { Syrjälä et } \\
\text { al., } 2013\end{array}$ & Yes & Yes & Yes & Yes & Yes & Yes & Yes & Yes & Partial & Partial & Partial & 0.86 \\
\hline $\begin{array}{l}\text { Samnieng, } \\
2014\end{array}$ & Yes & Yes & Yes & Yes & Yes & Yes & Partial & Yes & Yes & Yes & Yes & 0.95 \\
\hline $\begin{array}{l}\text { Iwasaki et } \\
\text { al., } 2016\end{array}$ & Yes & Yes & Yes & Yes & Yes & Yes & Yes & Yes & Yes & Yes & Yes & 1.00 \\
\hline $\begin{array}{l}\text { Ikebe et al., } \\
2006\end{array}$ & Yes & Yes & Yes & Partial & Yes & Yes & Yes & Yes & Partial & Yes & Yes & 0.91 \\
\hline $\begin{array}{l}\text { Yoshinaka } \\
\text { et al., } 2007\end{array}$ & Yes & Yes & Yes & Partial & Yes & Yes & Partial & Yes & Partial & Partial & Yes & 0.82 \\
\hline $\begin{array}{c}\text { Mesas et al., } \\
2010\end{array}$ & Yes & Yes & Yes & Yes & Yes & Yes & Yes & Yes & Yes & Yes & Yes & 1.00 \\
\hline
\end{tabular}




\begin{tabular}{|c|c|c|c|c|c|c|c|c|c|c|c|c|}
\hline $\begin{array}{l}\text { Poisson et } \\
\text { al., } 2014\end{array}$ & Yes & Yes & Yes & Yes & Yes & Yes & Yes & Yes & Partial & Partial & Yes & 0.91 \\
\hline $\begin{array}{c}\text { Soini et al., } \\
2003\end{array}$ & Yes & Partial & Yes & Yes & Yes & Partial & Partial & Yes & Partial & Partial & Yes & 0.77 \\
\hline $\begin{array}{l}\text { Solemdal et } \\
\text { al., } 2012\end{array}$ & Yes & Yes & Yes & Yes & Yes & Yes & Yes & Yes & Yes & Yes & Yes & 1.00 \\
\hline $\begin{array}{l}\text { Srinivasulu } \\
\text { et al } 2014\end{array}$ & Yes & Partial & Yes & Yes & Yes & Partial & Yes & Yes & No & Yes & Yes & 0.82 \\
\hline $\begin{array}{l}\text { Ikebe et al., } \\
2002\end{array}$ & Yes & Yes & Yes & Yes & Yes & Yes & Partial & Yes & Partial & Yes & Yes & 0.91 \\
\hline $\begin{array}{c}\text { Shinkawa et } \\
\text { al, } 2009\end{array}$ & Yes & Yes & Yes & Yes & Yes & Yes & Partial & Yes & Partial & Yes & Yes & 0.91 \\
\hline
\end{tabular}


Table 3. Objectives measurements to determine salivary hypofunction and corresponding cut-off values in the 15 selected studies

\begin{tabular}{|c|c|c|c|c|c|}
\hline Article & Parameters measured & Methodology & $\begin{array}{l}\text { Number of } \\
\text { measures }\end{array}$ & $\begin{array}{l}\text { Cut-off value to determine } \\
\text { hyposalivation }\end{array}$ & $\begin{array}{l}\text { References of the } \\
\text { methodology }\end{array}$ \\
\hline \multicolumn{6}{|c|}{ Articles that performed the measure of salivary flow to determine hyposalivation } \\
\hline $\begin{array}{l}\text { Dormenval et al., } \\
1998\end{array}$ & $\begin{array}{l}\text { Unstimulated salivary } \\
\text { flow rate, stimulated } \\
\text { salivary flow rate }\end{array}$ & $\begin{array}{c}\text { Measured during } 6 \text { min, spitting out each } 2 \text { min; } \\
\text { collected between } 9 \mathrm{~h} \text { and } 11 \mathrm{~h}\end{array}$ & 2 & $\begin{array}{l}\text { Unstimulated salivary flow } \\
\text { rate }<0,1 \mathrm{ml} / \mathrm{min} \text {, } \\
\text { Stimulated salivary flow rate } \\
\quad<0,5 \mathrm{ml} / \mathrm{min}\end{array}$ & (Sreebny et al. 1992) \\
\hline $\begin{array}{l}\text { Dormenval et al., } \\
1999\end{array}$ & $\begin{array}{l}\text { Unstimulated salivary } \\
\text { flow rate, stimulated } \\
\text { salivary flow rate }\end{array}$ & $\begin{array}{c}\text { Measured during } 6 \text { min, spitting out each } 2 \mathrm{~min} \text {; } \\
\text { Collected between } 9 \mathrm{~h} \text { and } 11 \mathrm{~h}\end{array}$ & 2 & $\begin{array}{l}\text { Unstimulated salivary flow } \\
\text { rate }<0,1 \mathrm{ml} / \mathrm{min} \text {, } \\
\text { Stimulated salivary flow rate } \\
\quad<0,5 \mathrm{ml} / \mathrm{min}\end{array}$ & (Sreebny et al. 1992) \\
\hline $\begin{array}{l}\text { Samnieng et al., } \\
2012\end{array}$ & $\begin{array}{l}\text { Unstimulated salivary } \\
\text { flow rate, stimulated } \\
\text { salivary flow rate }\end{array}$ & Measured during 5 minutes & 1 & $\begin{array}{l}\text { Unstimulated salivary flow } \\
\text { rate }<0,1 \mathrm{ml} / \mathrm{min} \\
\text { Stimulated salivary flow rate } \\
\quad<0,5 \mathrm{ml} / \mathrm{min}\end{array}$ & - \\
\hline $\begin{array}{l}\text { Syrjälä et al., } \\
2013\end{array}$ & $\begin{array}{l}\text { Unstimulated salivary } \\
\text { flow rate, stimulated } \\
\text { salivary flow rate }\end{array}$ & Measured during 5 minutes (draining method) & 1 & $\begin{array}{l}\text { Unstimulated salivary flow } \\
\text { rate }<0,1 \mathrm{ml} / \mathrm{min} \text {, stimulated } \\
\text { salivary flow rate }<1 \mathrm{ml} / \mathrm{min}\end{array}$ & $\begin{array}{l}\text { (Dormenval et al. } \\
\text { 1998, Flink et al. } \\
\text { 2008) }\end{array}$ \\
\hline Samnieng, 2014 & $\begin{array}{l}\text { Unstimulated salivary } \\
\text { flow rate }\end{array}$ & Measured during 5 minutes & 1 & $\begin{array}{l}\text { Unstimulated salivary flow } \\
\text { rate }<0,1 \mathrm{ml} / \mathrm{min}\end{array}$ & \\
\hline
\end{tabular}




\begin{tabular}{|c|c|c|c|c|c|}
\hline $\begin{array}{l}\text { Iwasaki et al., } \\
2016\end{array}$ & $\begin{array}{l}\text { Stimulated salivary } \\
\text { flow rate }\end{array}$ & $\begin{array}{c}\text { Measured during } 3 \text { minutes; Collected between } 9 \mathrm{~h} \text { to } \\
15 \mathrm{~h}\end{array}$ & 1 & $\begin{array}{l}\text { Stimulated salivary flow rate } \\
\qquad<0,5 \mathrm{ml} / \mathrm{min}\end{array}$ & (Hirotomi et al. 2006) \\
\hline Ikebe et al., 2006 & $\begin{array}{l}\text { Stimulated salivary } \\
\text { flow rate }\end{array}$ & $\begin{array}{l}\text { Measured during } 2 \text { minutes at their own pace; collected } \\
\text { between 10:00 am and 3:00 pm }\end{array}$ & 1 & $\begin{array}{l}\text { Stimulated salivary flow rate } \\
\qquad<0,5 \mathrm{ml} / \mathrm{min}\end{array}$ & $\begin{array}{l}\text { (Sreebny and Zhu } \\
\text { 1996, Ikebe et al. } \\
\text { 2002) }\end{array}$ \\
\hline $\begin{array}{l}\text { Yoshinaka et al., } \\
2007\end{array}$ & $\begin{array}{l}\text { Stimulated salivary } \\
\text { flow rate }\end{array}$ & Measured during 2 minutes at their own pace & 1 & $\begin{array}{l}\text { Stimulated salivary flow rate } \\
<0,5 \mathrm{ml} / \mathrm{min}\end{array}$ & (Michael E 2004) \\
\hline $\begin{array}{l}\text { Mesas et al., } \\
\quad 2010\end{array}$ & $\begin{array}{l}\text { Stimulated salivary } \\
\text { flow rate }\end{array}$ & No information provided & 1 & $\begin{array}{c}\text { Stimulated salivary flow rate } \\
<0,5 \mathrm{ml} / \mathrm{min} \text { Stimulated } \\
\text { salivary flow rate }< \\
0,7 \mathrm{ml} / \mathrm{min}\end{array}$ & $\begin{array}{l}\text { (Dormenval et al. } \\
\text { 1999, Ikebe et al. } \\
\text { 2002, Cabrera et al. } \\
\text { 2007, Flink et al. } \\
\text { 2008) }\end{array}$ \\
\hline $\begin{array}{l}\text { Poisson et al., } \\
\quad 2014\end{array}$ & flow under the tongue & $\begin{array}{c}\text { Measured by placing a sterile compress under the } \\
\text { tongue for } 5 \mathrm{~min}\end{array}$ & 1 & Salivary flow $<0,1 \mathrm{~g} / \mathrm{min}$ & - \\
\hline \multicolumn{6}{|c|}{ Articles that combined the measure of salivary flow rate with other measures of oral dryness } \\
\hline
\end{tabular}




\begin{tabular}{|c|c|c|c|c|c|}
\hline Soini et al., 2003 & $\begin{array}{l}\text { Unstimulated salivary } \\
\text { flow rate, stimulated } \\
\text { salivary flow rate, } \\
\text { Objective dry mouth }\end{array}$ & $\begin{array}{l}\text { Measured during } 5 \text { min (Unstimulated salivary flow } \\
\text { rate: let the saliva flow into the tube ; Stimulated } \\
\text { salivary flow rate: spitting out each } 1 \mathrm{~min} \text { ) ; collected } \\
\text { between } 9 \mathrm{~h} \text { and } 11 \mathrm{~h}\end{array}$ & 1 & $\begin{array}{l}\text { Unstimulated salivary flow } \\
\text { rate }<0,1 \mathrm{ml} / \mathrm{min}, \\
\text { stimulated salivary flow rate } \\
<0,8 \mathrm{ml} / \mathrm{min} \\
\text { Clinical dentist criteria }\end{array}$ & (Narhi et al. 1994) \\
\hline $\begin{array}{l}\text { Solemdal et al., } \\
2012\end{array}$ & $\begin{array}{l}\text { Stimulated salivary } \\
\text { flow rate, mirror test, } \\
\text { dry tongue }\end{array}$ & Measured during 3 minutes at their own pace & 1 & $\begin{array}{c}\text { Stimulated salivary flow rate } \\
<0,6 \mathrm{~g} / \mathrm{min} \\
\text { Dental mirror sticked to the } \\
\text { mucosa } \\
\text { Tongue completely devoid } \\
\text { of moisture }\end{array}$ & $\begin{array}{l}\text { (Henricsson et al. } \\
\text { 1990, Navazesh 1993) }\end{array}$ \\
\hline $\begin{array}{l}\text { Srinivasulu et al } \\
2014\end{array}$ & $\begin{array}{l}\text { Stimulated salivary } \\
\text { flow rate, } \\
\text { Total protein content, } \\
\text { calcium, pH, buffering } \\
\text { capacity }\end{array}$ & $\begin{array}{c}\text { Measured during } 5 \text { minutes at their own pace; collected } \\
\text { early in the morning }\end{array}$ & 1 & $\begin{array}{l}\text { Stimulated salivary flow rate } \\
\qquad<0,5 \mathrm{ml} / \mathrm{min}\end{array}$ & $\begin{array}{c}\text { (Navazesh and Kumar } \\
\text { 2008) }\end{array}$ \\
\hline \multicolumn{6}{|c|}{ Articles that used other method to determine hyposalivation } \\
\hline $\begin{array}{l}\text { Shinkawa et al., } \\
2009\end{array}$ & $\begin{array}{l}\text { Moisture of oral } \\
\text { mucosa }\end{array}$ & Measured at the right buccal mucosa, during $2 \mathrm{sec}$ & 3 & $28,3 \%$ of the $\mathrm{MCM}$ value & (Yamada et al. 2005) \\
\hline
\end{tabular}


